\title{
English yesterday and today
}

This is the first issue of ET in the 'post-McArthur era', edited by a new team, that happily still includes Tom. In preparing this issue, the new members of the squad became even more aware of Tom's editorial skills, the effort he has put into making ET succeed over 23 years and his general lightness of touch. It is entirely appropriate that this first issue therefore contain something of the old and the new in English studies. We decided to print, in the first half of this issue, short extracts from 6 seminal ET articles from its first 10 years, and invite the original authors to provide extended updates and comments.

David Crystal reviews his original article on the statistics of English, pinpointing the major growth areas of the last ten years. Jenny Cheshire looks back at the progress made towards reducing gender inequity in current English practice. Geoffrey Hughes discusses the history of war as embedded in the English lexicon, by referring to the major wars and acts of terror of the last 20 years. John Dougill writes on one of the roles that English continues to fulfil as a foreign language in the Japanese commercial and advertising world. Michael Rundell, who wrote a suite of three articles on the corpus revolution with Penny Stock in the early 1990s, updates these accounts by describing the astonishing power of the Internet today from which lexicographers and grammarians are now fully benefitting. The last update concerns Braj Kachru's account of how centre-periphery relations were changing in the late 1980s. As ill-health prevented Braj Kachru from meeting our deadline, a retrospect was instead provided by Rajend Mesthrie.

Of the new pieces, the first is a discussion by Miriam Meyerhoff of grammatical variation on the small Caribbean island of Bequia, using the tools of variationist sociolinguistics. The second is an insightful discussion of the language of thinking by Solveig Granath and Michael Wherrity, using insights from metaphor, etymology and cognitive linguistics. Innocent Chiluba examines the rise of SMS texting in Nigeria, against the background of the local features of Nigerian English. Brian Poole outlines the rise of a new construction in English 'I felt like I...', arguing that sportspersons may have a particular role in its dissemination.

We introduce a short piece on etymology written by Alex Tulloch, focussing on the origins of tennis terms. We hope to make etymology a regular feature of $E T$. Likewise, we intend to encourage the shorter miscellaneous contributions that make ET the lively, readable journal that it is: the notes and queries, crosswords, short book-reviews and the like. Finally, the new publication months for ET are March, June, September and December.

The Editors

The editorial policy of English Today is to provide a focus or forum for all sorts of news and opinion from around the world. The points of view of individual writers are as a consequence their own, and do not reflect the opinion of the editorial board. In addition, wherever feasible, ET generally leaves unchanged the orthography (normally British or American) and the usage of individual contributors, although the editorial style of the journal itself is that of Cambridge University Press.

English Today (ISSN 0266-0784) is published quarterly by Cambridge University Press, The Edinburgh Building, Shaftesbury Road, Cambridge CB2 8RU, UK / Cambridge University Press, 32 Avenue of the Americas, New York, N.Y. 10013-2473.

๑) Cambridge University Press 2008. No contents may be reproduced by any means without the permission of Cambridge University Press.

\section{Subscriptions:}

The 2008 subscription price (excluding VAT) for four issues for libraries and institutions, which includes print and electronic access, is $f 101$ outside of North America; $\mathrm{f} 34$ for individuals; $f 25$ for students and the retired. The electronic-only price available to institutional subscribers is $\mathrm{fg5}$. Prices include delivery by air where appropriate. Apply to journals@cambridge.org.

\section{Advertising Sales:}

write to the Advertising Promoter at the above address.

Email: ad_sales@cambridge.org

\section{USA, CANADA AND MEXICO:}

\section{Subscriptions:}

The 2008 subscription price (excluding VAT) for four issues for libraries and institutions, which includes print and electronic access, is $\$ 171$ in USA, Canada and Mexico; $\$ 54$ for individuals; $\$ 39$ for students and the retired. The electronic-only price available to institutional subscribers is \$157. Apply to journals_subscriptions @cup.org or Cambridge University Press, 100 Brook Hill Drive, West Nyack, N.Y. 10994-2133.

\section{Advertising Sales:}

write to the Advertising Coordinator at the above address.

Periodicals postage paid at New York, $\mathrm{NY}$ and at additional mailing offices.

POSTMASTER: Send address changes to English Today, Cambridge University Press, 100 Brook Hill Drive, West Nyack, N.Y. 10994-2133.

Japanese prices for institutions are available from Kinokuniya Company Ltd, P.O. Box 55, Chitose, Tokyo 156, Japan.

\section{Contacting the Editors:}

Please e-mail Sarah Rowan, our editorial assistant in Cape Town at <englishtoday@telkomsa.net>.

Internet access This journal is included in the Cambridge Journals Online service which can be found at http://uk.cambridge.org/journals. For further information on other Press titles access http://uk.cambridge.org.

Designed and typeset by Peter Ducker. Printed in the United Kingdom at the University Press, Cambridge. 